Final version published. Pena-López, Atilano and Sánchez-Santos, J.M. (2008): Effects of competition on religious markets: some empirical evidence, Applied Economics Letters, 15, pp. 371-374.

\title{
Effects of competition on religious markets: some empirical evidence
}

José Atilano Pena López (atilano@udc.es)

José Manuel Sánchez Santos (santos67@udc.es)

University of A Coruña

Spain

\section{ABSTRACT}

The aim of this paper is to assess, from an empirical point of view, the relative explanatory capacities of two hypotheses that address the link between economics and religion: the religious markets and the secularization hypothesis. First, we estimate a baseline model that takes into account both hypotheses jointly. Secondly, we study in a separate way the influence of socio-economic development and market structure. Finally, we investigate the relationship between group size and religious commitment. Overall, the results suggest some supporting evidence for the predictions derived from the hypothesis of religious markets that emphasize the overriding importance of the degree of competition as a determinant factor of religious behaviours.

Key words: economics of religion, hypothesis of secularization, religious markets

JEL Codes: A13, Z12

\section{1. - Introduction.}

The study of Religion has a long tradition in sciences like Sociology, Psychology, Anthropology and even Political Science. The predominant paradigm in these approaches is known as "the hypothesis of secularization". ${ }^{1}$ The deductive logic of this theory is remarkably clear: economic development entails income 
Final version published. Pena-López, Atilano and Sánchez-Santos, J.M. (2008): Effects of competition on religious markets: some empirical evidence, Applied Economics Letters, 15, pp. 371-374.

growth, higher levels of education, urbanization and life expectancy, as well as changes in natality and demographic structure. All these transformations would lead to a gradual reduction in religious practice and in the demand of religious services.

The Economics of Religion, as an economic analysis of the religious behaviours and markets, constitutes an alternative perspective. There is a significant literature which assumes as a starting point the analogy between religious and economic behaviour in such a way that religions and institutions performance would be explicable with market categories. A sampling of such works includes Stark and Bainbridge (1987); Baimbridge and Whyman (1997), Iannaccone (1991, 1997 and 1998), Smith, Sawkins and Seaman (1998) and, more recently, Smith and Sawkins (2003), North and Gwin (2004).

The present paper seeks to provide empirical foundations for opposing both the secularization and the religious markets hypotheses. In order to investigate separately the relationship between religious participation, socioeconomic development and market concentration the paper is organized as follows. After assessing the validity of the secularization hypothesis, we develop an empirical contrast of two additional hypotheses derived from the hardcore of the religious markets paradigm. First, we test if higher competition between denominations gives rise to a higher efficiency in the provision of religious services. Secondly, we investigate if the organizations smaller in size or with a smaller market share are more efficient. Finally we summarize the main conclusions.

\footnotetext{
${ }^{1}$ For a review of the literature about secularization hypothesis see Wilson (1982)
} 
Final version published. Pena-López, Atilano and Sánchez-Santos, J.M. (2008): Effects of competition on religious markets: some empirical evidence, Applied Economics Letters, 15, pp. 371-374.

\section{Determinant factors of religious participation}

Our empirical analysis about the determinant factors of religious participation uses data on participation, belief and market share of 58 countries with different religious traditions. The set of data was obtained from the World Values Survey 1995-1999 (2000). Participation in the communitarian celebrations, measured as the percentage of individuals who claim to attend the religious services at least once a week, is chosen as a proxy of religious demand and commitment with the congregation.

In the baseline case, we assume that religious participation depends on both the secularisation process and market structure. Specifically,

$$
\mathrm{P}_{\mathrm{j}}=\alpha+\beta \mathrm{HDI}_{\mathrm{j}}+\gamma \mathrm{H}_{\mathrm{j}} \quad[1]
$$

where $P_{j}$ is the level of religious participation in country $j, H_{\mathrm{HDI}}$ (Human Development Index) is the indicator of socioeconomic development of country $\mathrm{j}$ that incorporates the factors emphasized by the secularization hypothesis (education, income and life expectancy); $\mathrm{H}_{\mathrm{j}}$ is an Herfindahl index defined as $H_{j}=\sum_{i} S_{i j}^{2}$, where $S_{i j}$ is the share of the religious market of confession i in country

j. The values of the market concentration index are indicative of the size of confession in a market. In turn, that index is a measure of the diversity of confessions within a market and, consequently, it can be considered as a proxy of competition levels.

This regression model shows both variables the socioeconomic development (HDI) and market concentration (H) as significant (see model 1 in table 1). To investigate this issue further, the model specification is modified introducing a dummy variable in order to differentiate between Catholic and 
Final version published. Pena-López, Atilano and Sánchez-Santos, J.M. (2008): Effects of competition on religious markets: some empirical evidence, Applied Economics Letters, 15, pp. 371-374.

Islamic traditions and other confessions. This distinction of dominant denominational traditions becomes relevant; indeed, countries with a Catholic or Islamic majority reveal a greater level of participation (models 2 and 3). Nevertheless, these results do not allow for any discrimination between the respective explanatory capacities of both paradigms the secularization and the religious markets hypotheses.

\section{[Table 1]}

\subsection{Secularization hypothesis}

Verification of the secularization hypothesis would imply the existence of a significant negative relation between the religious participation and socioeconomic development. Then,

$$
P_{j}=a+\beta H D I_{j}
$$

The results of estimating equation [2] provide some weak evidence in favour of the secularization hypothesis (model 4). ${ }^{2}$ Furthermore, there is stronger evidence supporting the predictions of the secularization hypothesis in countries with a Catholic and Islamic tradition (model 5).

\subsection{Religious market hypothesis}

If it is assumed that a single confession is unable to reflect all religious demands, ${ }^{3}$ it is possible to advance the hypothesis that an increase of competition

\footnotetext{
${ }^{2}$ See Barro and McCleary (2003) for some empirical evidence on the influence of factors such as education and urbanization on religious participation.

${ }^{3}$ Isaacs and Laband (1999) find some evidence on the relationship between social heterogeneity and religious pluralism. Baimbridge and Whyman (1997) also suggest the existence of supply-side effects on religious demand.
} 
Final version published. Pena-López, Atilano and Sánchez-Santos, J.M. (2008): Effects of competition on religious markets: some empirical evidence, Applied Economics Letters, 15, pp. 371-374.

in religious markets will cause a greater level of religious participation and, therefore, it would improve the efficiency in the provision of religious services. According to this hypothesis, religious participation $\left(\mathrm{P}_{\mathrm{j}}\right)$ would be a function of market concentration expressed through a Herfindahl index $\left(\mathrm{H}_{\mathrm{j}}\right)$ :

$$
P_{j}=a+\beta H_{j}
$$

If there is a negative relation between the religious participation and the degree of concentration of this market, participation will be smaller in those contexts in which the religious markets are monopolized or subsidized by the State (Public Religion) than in a situation of free competition. ${ }^{4}$

At first glance, the correlation between religious participation and market concentration is practically non-existent (model 6). However, as we did before, it is necessary to consider different market structures. In particular, the evidence reflected in table 3 suggests the existence of two general sorts of religious market management. The first type refers to non-Catholic and non- Islamic countries and it can be defined as an open market model in which monopoly and public religion seem to cause weak commitment levels (model 8). The second type is a framework in which the Catholic Church or the diverse Islamic confessions generate high levels of participation in spite of being official or semi-official religious (model 7).

The results corresponding to the specification of model 8 also allow us to conclude that in non-catholic and non-islamic countries (with a lutheran and calvinist tradition as well as in Anglo-Saxon and Ortodox countries) the hypothesis of religious markets is verified. Moreover, the degree of competition

\footnotetext{
${ }^{4}$ By contrast, the results obtained by Hull and Bold (1998) appear to contradict the standard religious markets hypothesis.
} 
Final version published. Pena-López, Atilano and Sánchez-Santos, J.M. (2008): Effects of competition on religious markets: some empirical evidence, Applied Economics Letters, 15, pp. 371-374.

in the market is also the main factor determining participation and group commitment.

Overall, the empirical evidence supports the hypothesis of the religious markets and the secularization processes in Catholic and Islamic countries. On the other hand, in those countries involved in secularization processes, a high level of market concentration and the existence of monopolies seem to favour a stronger religious commitment.

\subsection{Commitment and group size.}

An additional hypothesis derived from the religious markets paradigm can be formulated as follows: Assuming the non-existence of scale economies in provision of religious services, religious groups will generate a greater level of the commitment among their members the smaller their share in the religious market. To investigate the relationship between commitment and size of the group we regressed to the following equation:

$$
P_{i j}=c+\gamma S_{i j}
$$

where $P_{i j}$ is the religious participation in group i of country j and $S_{i j}$ is the market share of congregation $i$.

The main results of the econometric estimation of equation [3] support the existence of an inverse relation between the congregation's relative size (market share) and the levels of individuals' commitment and religious participation (model 9). If we run a regression for those countries in which Catholic and Islamic are not majority traditions, the explanatory capacity of market share increases to the extent that the most important effects on religious behaviour are associated with this factor (model 10). 
Final version published. Pena-López, Atilano and Sánchez-Santos, J.M. (2008): Effects of competition on religious markets: some empirical evidence, Applied Economics Letters, 15, pp. 371-374.

\section{3.- Conclusions.}

This paper provides preliminary results as supporting evidence for the predictions that emerge from the economic approach that emphasises the relationship between a religious market structure and religious behaviour. In particular, the empirical outcomes reflect the existence of a causal and direct link between the level of competition in the religious markets and the levels of religious participation and commitment.

The results obtained do not allow us to reject the hypothesis of secularization, but to put forward an alternative hypothesis (the religious market hypothesis) that would constitute a progress in understanding the relation between economics and religion. This is because the latter hypothesis has a comparable explanatory capacity of the evolution of the demand for religion, but, unlike the former one, it could also explain the evolution of religious participation.

Some of the specific features observed in the catholic and the Islamic are entirely consistent with the premises of the religious markets hypothesis. Both traditions do not constitute a monopoly and do not strictly adjust to the pattern of the model of public religion. In fact, they have allowed a surprising diversity of practices (orders and congregations) and levels of membership that could be considered as a substitute of competition. However, the advances in the processes of secularization in Catholic and Islamic countries along with a higher religious pluralism could change the market structures.

\section{References}

Baimbridge, M. and P. Whyman (1997), "Demand for religion in the British Isles”, Applied Economics Letters, 4, 79-82. 
Final version published. Pena-López, Atilano and Sánchez-Santos, J.M. (2008): Effects of competition on religious markets: some empirical evidence, Applied Economics Letters, 15, pp. 371-374.

Barro, R., and R. McCleary (2003), Religion and economic growth, NBER Working Paper. n 9682.

Hull, B.S. and F. Bold (1998), "Product variety in religious markets", Review of Social Economy, 56:1, 1-19.

Iannaccone, L. (1991), "The consequences of religious market structure", Rationality and Society, 3, 156-177.

Iannaccone, L. (1997), "Deregulating religion: the economics of church and state", Economic Inquiry, 35, 350-364.

Iannaccone, L. (1998) "Introduction to the economics of religion", Journal of Economic Literature, 36, 1473-1507.

Isaacs, J.P. and D.N. Laband (1999), "Within-group homogeneity and exit in religious clubs", Applied Economics Letters, 6, 805-808.

North, Ch. and C. Gwin (2004), "Religious Freedom and the unintended consequences of state religion”, Southern Economic Journal, 71, 103-117.

Stark, R. and W. Bainbridge (1987), A theory of religion, New York: J.P.Lang. Smith, I. and J.W. Sawkins (2003), "The economics of regional variation in religious attendance", Applied Economics, 35, 1577-1588.

Smith, I.; Sawkins, J.W. and P.T. Seaman (1998), "The economics of religious participation, a cross-country study, Kyklos, 51, 25-43.

Wilson, B. (1982) Religion in Sociological Perspective, Oxford University Press. Oxford.

World Values Survey 1995-1999 (2000), Ed. Análisis Sociológicos Económicos y Políticos. Madrid. 
Final version published. Pena-López, Atilano and Sánchez-Santos, J.M. (2008): Effects of competition on religious markets: some empirical evidence, Applied Economics Letters, 15, pp. 371-374. 
Final version published. Pena-López, Atilano and Sánchez-Santos, J.M. (2008): Effects of competition on religious markets: some empirical evidence, Applied Economics Letters, 15, pp. 371-374.

TABLE 1: Determinants of religious participation

\begin{tabular}{|c|c|c|c|c|c|c|c|c|c|c|}
\hline & \multicolumn{3}{|c|}{ Baseline case } & \multicolumn{2}{|c|}{ Participation vs. H.D.I } & \multicolumn{3}{|c|}{ Participation vs. competition } & \multicolumn{2}{|c|}{ Participation vs. market share } \\
\hline & Model 1 & Model 2 & Model 3 & Model 4 & Model 5 & Model 6 & Model 7 & Model 8 & Model 9 & Model 10 \\
\hline Market concentration $(\mathrm{H})$ & $-32.255^{*}$ & $-42.675^{* *}$ & & & & $-32.024 *$ & & & & \\
\hline Log (Market concentration) & & & $-23.038^{* *}$ & & & & $26.560 * *$ & & & \\
\hline HDI & $-68.54 * *$ & $-73.909^{* *}$ & $-71.543^{* *}$ & $-93.605 * *$ & $-72.541 * *$ & & & & & \\
\hline $\begin{array}{c}\text { Confession } * \text { market } \\
\text { concentration }\end{array}$ & & & & & & & $33.668 * *$ & & & \\
\hline $\begin{array}{l}\text { LOG(market concentration) } \\
\text { (non catholic, non islamic) }\end{array}$ & & & & & & & & $-35.32451 * *$ & & \\
\hline LOG( Market share) & & & & & & & & & $-0.074818^{* *}$ & \\
\hline $\begin{array}{c}\text { LOG (Market share) } \\
\text { ( non catholic, non islamic) }\end{array}$ & & & & & & & & & & $-0.100664 * *$ \\
\hline Catholic and Islamic & & $19.26^{* *}$ & $19.649^{* * *}$ & & $15.862 * *$ & & & & & \\
\hline $\mathrm{C}$ & $98.248 * *$ & $102.191^{* *}$ & $61.356^{* *}$ & $101.5217 * *$ & $78.248 * *$ & $42.866^{* *}$ & & $-9.104255 * *$ & $0.203504 * *$ & $0.103746^{* *}$ \\
\hline$R^{2}$ & 0.188 & 0.365 & 0.402 & 0.226031 & 0.28210 & 0.075348 & 0.432400 & 0.511597 & 0.270516 & 0.415616 \\
\hline $\mathbf{R}^{2}$ Adjusted & 0.158 & 0.330 & 0.369 & 0.210236 & 0.26321 & 0.058837 & 0.421271 & 0.492060 & 0.266395 & 0.411693 \\
\hline Durbin-Watson & 2.14 & 1.870 & 1.825 & 1.859726 & 1.921005 & 2.226 .7 & 2.071141 & 1.913512 & 1.595812 & 1.728768 \\
\hline $\operatorname{Prob}(\mathbf{F})$ & 0.003 & 0.000 & 0.000 & 0.000422 & 0.00003 & 0.0370 & 0.000000 & 0.000028 & 0.000000 & 0.000000 \\
\hline Observations & 58 & 58 & 58 & 58 & 58 & 58 & 58 & 30 & 172 & 152 \\
\hline
\end{tabular}

*indicates statistically significat at $5 \%$ level; ** at $1 \%$ 